\title{
The Research of Stability for Reconstruction Project of Sluice in Baihe Dazhantou
}

\author{
Meng-Ying BIAN ${ }^{1, a}$, Lei TANG ${ }^{2, b^{*}}$, Hui $\mathrm{CHEN}^{3}$, Jia-Peng MEI ${ }^{4}$ \\ ${ }^{1}$ College of Constructional Engineering, Kunming University of Science and Technology, Kunming, \\ China \\ ${ }^{2,3,4}$ College of Water Conservancy and Hydropower Engineering, Hohai University, Nanjing, China \\ amengyingbian@126.com, ${ }^{\mathrm{b} t \mathrm{t} 040258 @ 126 . c o m}$ \\ ${ }^{*}$ Corresponding author
}

Keywords: Chamber, Retaining Wall, Stability.

\begin{abstract}
Currently, there are more and more sluice construction projects, and the demands of project qualities continue to improve. In sluice design researches, stability study may be very difficult. Combining with the practical project, this paper analyzes the stability of sluice chamber and retaining wall in detail and summarizes the calculation process, which can be the reference to other similar projects in the research of stability.
\end{abstract}

\section{Project Overview}

Baihe Dazhantou sluice project is located at Bai River near Dazhantou village, which is $8 \mathrm{~km}$ far from Xindian Township, Wancheng District, Nan yang. Flow rate from the sluice is more than $5000 \mathrm{~m}^{3} / \mathrm{s}$. The level of project is large I. The level of main building is 1 , the secondary is 2 and temporary is 4. This project is the headwork of Baitong canal in Yahekou irrigated area.

The new sluice is in the original headwork movable dam location basically. It is divided into upstream connection section, control section, stilling pool section, apron extension section, anti-scour trench segment, the right bank diversion dyke protection section and the left bank downstream protection section.

Sluice chamber consists of 24 holes, it is open type structure. Two holes make up one unit; it has a total units of 12. The single span width is 12 meters, total width is 332 meters. Surface elevation of sluice board is 133 meters and top level is 140.20 meters. Designed water level in front of sluice is 136.8 meters. When hundred-year flood is coming, water level in front of sluice is 138.4 meters; level of tail water is 138.19 meters. Water level in front of sluice is 139.16 meters, tail water level is 138.81 meters under the condition of two hundred-year check flood.

Hoist room is set on the sluice pier. On both sides of the sluice chamber set bridgehead, Hoist room is set on the sluice pier. On both sides of sluice chamber set bridgehead. The access bridge is under hoist room. The vertical seepage project is set up in front of sluice board. This sluice project adopts energy dissipation by underflow method. The fold beam steel gate is used as bulkhead gate and the flat steel gate is used as working gate, starting and stopping with lifting hoist.

In order to increase seepage paths, sluice chamber along with key-wall has a high-pressure sprinkle wall with average depth of 19 meters; the bottom of the stilling pool behind sluice is laying macadam, which has a thickness of 0.15 meters. Drain system is paved at the bottom of stilling pool, it's distribution likes plum blossom. There are 1-meter depth alveolus lay in front of sluice and behind the sluice toe.

\section{The Research of Sluice Chamber Stability}

Sluice chamber stability study mainly includes calculating the stability of sliding resistance, the maximum base stress and the no-uniformity coefficient of stress on basement. Sluice chamber stability calculations take sections between two adjacent permanent seams as a cell. The structure of chamber is monolithic, seams are in piers. The calculating processes consider one-sided stability 
calculation and bilateral stability calculation of two holes as a unit in the middle of chambers, bilateral stability calculation of two holes as a unit on the edges [1].

\section{Working Condition of Calculation and Load Combination}

Computational load combinations include fundamental load combination and the special load combination [2].

The following 3 kinds of working conditions have been taken into account during the stability calculation as fundamental load combination:

(1)Working condition of completion period: there is no water before and behind the sluice chamber;

(2)Working condition of retaining water in the highest level: Water level before sluice is design water level, there is no water behind the sluice;

(3)Working condition of flood discharging under design flood level condition: Water level is 138.40 meters high before sluice and 138.19 meters high behind it.

The following 2 kinds of working conditions have been taken into account during the stability calculation as special load combination:

(1)Working condition of flood discharging under maximum flood level: Water level is 139.16 meters high before sluice and 138.81 meters high behind it;

(2)Working condition of maintenance: Water level is 136.8 meters high. One hole is retaining water by bulkhead gate, the other is retaining by service gate, and there is no water behind the sluice.

\section{External Load Calculation}

Roof of hoist room: $G_{1}=1171 \mathrm{kn}$, brick wall of hoist room: wall height is $4.2 \mathrm{~m}$; unit weight of wall is $18 \mathrm{kn} / \mathrm{m}^{3}, G_{2}=1376.1 \mathrm{kn}$; soleplate of hoist room: $G_{3}=2531 \mathrm{kn}$, framed bent: $G_{4}=200.4 \mathrm{kn}$, hoist: $G_{5}=5.4 \mathrm{kn}$, access bridge: $G_{6}=628.7 \mathrm{kn}$, sluice gate: $\rho=7850 \mathrm{~kg} / \mathrm{m}, G_{7}=5350 \mathrm{kn}$, breast wall: $G_{8}=158.76 \mathrm{kn}$, gate pier: $G_{9}=6879 \mathrm{kn}$, baseboard: $G_{10}=10836.84 \mathrm{kn}$.

Hydrostatic pressure:

$$
P=\frac{\rho g h^{2}}{2}
$$

Wind pressure normal to the vertical surfaces of the building is calculated according to the following formula [3]:

$$
W_{k}=\beta_{z} \mu_{s} \mu_{z} w_{0}
$$

\section{Results of Stability Calculation}

According to the situation of exploration data and layout of the sluice chamber, sluice base is located in the sandy pebble layer behind foundation treatment. The suggesting geological parameters are friction of concrete and foundation $\mathrm{f}=0.5$, Standard capacity is $400 \mathrm{kPa}$.

Because of the sluice floor slab is equipped with high- pressure sprinkle wall, pressure head of seepage water pressure has reduced in diaphragm wall. Diaphragm wall has average depth of 19 meters. Incremental seepage path length is 38 meters. Reduction factor of osmotic pressure intensity is 0.28 .

The method of calculating the anti-slide safety factor in sluice base uses the strength calculation formula on shear resistance [2]:

$$
K_{c}=f \times \frac{\sum G}{\sum P} .
$$


Where $K_{C}$ is safety factor sliding; $\quad t$ is the shear friction coefficient of contact element between lock chamber and foundation; $\Sigma G$ is all the vertical loads upon lock chamber; $\Sigma P$ is all the horizontal loads upon lock chamber.

For the gate of symmetrical structure arrangement and the stress distribution, Lock chamber basal pressure calculation often uses computational formula in mechanics of materials:

$$
\sigma_{\min }^{\max }=\frac{\sum G}{b}\left(1 \pm \frac{6 e}{b}\right) .
$$

Where $\sigma_{\min }^{\max }$ are the maximum and the minimum pressure in basement of sluice chamber; $\Sigma G$ is the entire vertical loads upon lock chamber; $b$ is the bottom width of lock chamber foundation; $e$ is eccentricity of load.

Lock chamber basal pressure calculation uses two-way computing method, when middle unit's one hole is under repair or the unit is on the edge. Computation formula is as follows [2]:

$$
\sigma_{3,4}^{1,2}=\bar{\sigma} \pm \frac{\sum M_{x}}{W_{x}} \pm \frac{\sum M_{Y}}{W_{y}}
$$

Where $\sigma_{3,4}^{1,2}$ is contact stress of lock chamber's four corners; $2 G$ is the entire vertical loads upon lock chamber; $\mathrm{W}$ is the moment of Lock chamber bottom foundation for the direction of the base perpendicular to the flow direction; $\sum M x, \sum M y$ are the entire total moment that all the vertical loads and horizontal loads, upon lock chamber to centroid axis Perpendicular to the flow direction and Along with flow direction.

Tab. 1 Stability Calculation Results of Middle Units

\begin{tabular}{|c|c|c|c|c|c|c|}
\hline \multirow{2}{*}{$\begin{array}{c}\text { working condition } \\
\text { of calculation }\end{array}$} & $\begin{array}{c}\text { anti-slide } \\
\text { safety } \\
\text { factor } \\
\text { Kc }\end{array}$ & \multicolumn{2}{|c|}{ foundation stress $\sigma[\mathrm{kPa}]$} & $\begin{array}{c}\text { non-uniformity } \\
\text { coefficient } \\
\eta\end{array}$ & $\begin{array}{c}\text { design } \\
\text { value of } \\
\text { allowable } \\
\text { load } \\
\text { capacity } \\
{[\mathrm{kPa}}\end{array}$ \\
\cline { 3 - 7 } & - & 99.80 & 104.49 & 102.14 & 1.05 & 400 \\
\hline $\begin{array}{c}\text { completion period } \\
\text { retaining water in } \\
\text { the highest level }\end{array}$ & 5.91 & 100.67 & 112.53 & 106.60 & 1.12 & 400 \\
\hline $\begin{array}{c}\text { flood discharging } \\
\text { under design flood } \\
\text { level condition }\end{array}$ & - & 78.06 & 82.76 & 80.41 & 1.06 & 400 \\
\hline $\begin{array}{c}\text { flood discharging } \\
\text { under maximum } \\
\text { flood level } \\
\text { condition }\end{array}$ & - & 77.08 & 81.78 & 79.43 & 1.06 & 400 \\
\hline $\begin{array}{c}\text { Working condition } \\
\text { of maintenance }\end{array}$ & 5.58 & 103.48 & 99.90 & 101.69 & 1.04 & 400 \\
\hline
\end{tabular}


Tab. 2 Stability Calculation Results of Marginal Units

\begin{tabular}{|c|c|c|c|c|c|c|c|c|}
\hline \multirow{2}{*}{$\begin{array}{l}\text { working } \\
\text { condition of } \\
\text { calculation }\end{array}$} & \multirow{2}{*}{$\begin{array}{l}\text { anti-slide } \\
\text { safety } \\
\text { factor } \\
\text { Kc }\end{array}$} & \multicolumn{5}{|c|}{ foundation stress $\sigma[\mathrm{kPa}]$} & \multirow{2}{*}{$\begin{array}{c}\text { non-uniformity } \\
\text { coefficient } \\
\eta\end{array}$} & \multirow{2}{*}{$\begin{array}{c}\text { design } \\
\text { value of } \\
\text { allowable } \\
\text { load } \\
\text { capacity } \\
{[\mathrm{kPa}]}\end{array}$} \\
\hline & & $\sigma_{1}$ & $\sigma_{2}$ & $\sigma_{3}$ & $\sigma_{4}$ & $P_{\text {average }}$ & & \\
\hline $\begin{array}{l}\text { completion } \\
\text { period }\end{array}$ & 4.01 & 118.35 & 99.13 & 114.79 & 95.57 & 108.30 & 1.24 & 400 \\
\hline $\begin{array}{c}\text { Retaining } \\
\text { water in the } \\
\text { highest level }\end{array}$ & 3.49 & 130.06 & 110.84 & 114.03 & 11.73 & 96.00 & 1.37 & 400 \\
\hline $\begin{array}{c}\text { flood } \\
\text { discharging } \\
\text { under } \\
\text { design flood } \\
\text { level } \\
\text { condition }\end{array}$ & 3.18 & 96.28 & 77.06 & 92.73 & 12.49 & 82.00 & 1.31 & 400 \\
\hline $\begin{array}{c}\text { Flood } \\
\text { discharging } \\
\text { under } \\
\text { maximum } \\
\text { flood level } \\
\text { condition }\end{array}$ & 2.43 & 76.03 & 91.70 & 91.70 & 72.48 & 80.97 & 1.31 & 400 \\
\hline $\begin{array}{c}\text { Working } \\
\text { condition of } \\
\text { maintenance }\end{array}$ & 2.42 & 136.51 & 118.42 & 94.43 & 76.35 & 87.74 & 1.79 & 400 \\
\hline
\end{tabular}

Stability calculation results of middle unit and marginal unit can be seen in Table 1, Table 2 .

\section{Sluice Chamber Stability Analysis}

Anti-slide safety factor of level 1 sluice is not less than 1.35 when load combination is the fundamental combination, and it is not less than 1.2 when load combination is the special combination. Non-uniform coefficient of clay foundation is not greater than 2.0 when load combination is the fundamental combination and it is not greater than 2.5 when load combination is the special combination. The maximum of foundation stress is not greater than 1.2 times of foundational allowable load capacity. Those calculations demonstrate that anti-slide safety factor, the maximum of foundation stress and stress non-uniformity coefficient of sluice chambers are satisfied. So, the design for sluice chambers is safety.

\section{The Research of Wing Walls Stability in the Upstream and Downstream of Sluice}

\section{Basic Parameters}

The wing wall on the right bank of sluice upstream is circular semi-gravity wall, radius of arc is 20 meters. The wall in left bank is connected with sluice. Splayed semi-gravity wall is used as wing wall in stilling pool, diffusion angle is 11 degrees. The wing wall in apron section uses splayed semi-gravity wall, which is connected with banks, radius of arc in left bank is 20 meters and it is 15 meters in right bank.

In order to avoid by-pass seepage, filling soil behind wall is weight loam. Physical mechanical indexes are as follows: internal friction angle $\phi=25^{\circ}$, cohesive force is not considered infilling soil behind wall, soil natural density $\gamma=19.5 \mathrm{kn} / \mathrm{m}^{3}$, the buoyant density is $\gamma^{\prime}=10 \mathrm{kn} / \mathrm{m}^{3}$. C20 
reinforced concrete is used in wing walls, the density is $\gamma=24.5 \mathrm{kn} / \mathrm{m}^{3}$. According to the exploration data and sluice chamber arrangement, the floor of retaining wall is located in the sandy pebble layer, it's suggested geologic parameters value is friction coefficient of concrete and foundation $\mathrm{f}=0.5$. Foundation bearing layer is located in the sandy pebble layer, it's standard value of bearing capacity $\mathrm{f}_{\mathrm{k}}$ is $400 \mathrm{kPa}$.

\section{Working Condition of Calculation}

The 4 kinds of working condition have been taken into account during the calculation of wing wall stability:

(1)Working condition of completion period;

(2)Working condition of retaining water in the highest level;

(3)Working condition of retaining water in the check water level;

(4)Working condition of sudden drawdown: There is on water before the wall, but depth of water behind the wall is one third of the high of wall.

\section{Stability Calculation Result}

The method of calculating the anti-slide safety factor is using the strength calculation formula on shear resistance [2]:

$$
K_{c}=f \times \frac{\sum G}{\sum H} .
$$

Where $K_{c}$ is anti-slide safety factor; (under the fundamental load combination, $K_{c}=1.35$; under the special load combination, $\left.K_{c}=1.20\right) ; \quad t$ is the shear friction coefficient of contact element between lock chamber and foundation; $\Sigma G$ is the entire vertical load upon lock chamber; $\sum H$ is the entire horizontal loads upon lock chamber.

The calculation of basement stress uses computational formula in mechanics of materials:

$$
\sigma_{\min }^{\max }=\frac{\sum G}{A}\left(1 \pm \frac{6 e}{B}\right) .
$$

Where $\sigma_{\max }, \sigma_{\min }$ are the maximum and the minimum pressure on basement; $\sum G$ is the entire vertical load upon basement; $A$ is area of basement; $B$ is width of basement; e is eccentricity of resulting force point to base center.

The calculation of stress non-uniformity coefficient uses the following formula:

$$
\eta=\sigma_{\max } / \sigma_{\min }<[\eta]
$$

Where $\eta$ is practical stress distribution non-uniformity coefficient; $[\eta]$ is admissible value of ratio that the maximum and minimum stress ( on the fundamental load combination, $\eta=2.0$; on the special load combination, $\eta=2.5$ ).

Because of non-uniformity coefficient met the requirements, so the calculation of anti-overturning stability is needless.

Stability calculation results can be seen in Table 3 and Table 4. 
Tab. 3 Stability Calculation Results of Wing Wall on Inlet Area.

\begin{tabular}{|c|c|c|c|c|c|}
\hline \multirow[t]{2}{*}{$\begin{array}{c}\text { load } \\
\text { combination }\end{array}$} & \multirow[t]{2}{*}{$\begin{array}{l}\text { working condition } \\
\text { of calculation }\end{array}$} & \multirow{2}{*}{$\begin{array}{c}\begin{array}{c}\text { anti-slide } \\
\text { safety } \\
\text { factor }\end{array} \\
\text { Kc }\end{array}$} & \multicolumn{2}{|c|}{$\begin{array}{c}\text { foundation } \\
\text { stress } \\
{[\mathrm{kPa}]}\end{array}$} & \multirow{2}{*}{$\begin{array}{c}\begin{array}{c}\text { non-uniformity } \\
\text { coefficient }\end{array} \\
\eta\end{array}$} \\
\hline & & & $\mathrm{P}_{\max }$ & $P_{\text {min }}$ & \\
\hline \multirow{2}{*}{$\begin{array}{l}\text { fundamental } \\
\text { load } \\
\text { combination }\end{array}$} & $\begin{array}{l}\text { working condition } \\
\text { of completion } \\
\text { period }\end{array}$ & 1.688 & 144.63 & 121.7 & 1.188 \\
\hline & $\begin{array}{l}\text { working condition } \\
\text { of retaining water } \\
\text { in the highest level }\end{array}$ & 1.48 & 114.91 & 72.82 & 1.578 \\
\hline \multirow{2}{*}{$\begin{array}{l}\text { special load } \\
\text { combination }\end{array}$} & $\begin{array}{c}\text { working condition } \\
\text { of retaining water } \\
\text { in the check water } \\
\text { level }\end{array}$ & 1.718 & 89.16 & 63.95 & 1.394 \\
\hline & $\begin{array}{c}\text { working condition } \\
\text { of sudden } \\
\text { drawdown }\end{array}$ & 1.375 & 147.03 & 92.32 & 1.593 \\
\hline
\end{tabular}

Tab. 4 Stability Calculation Results of Wing Wall on Outlet Area.

\begin{tabular}{|c|c|c|c|c|c|}
\hline \multirow{2}{*}{$\begin{array}{c}\text { load } \\
\text { combination }\end{array}$} & $\begin{array}{c}\text { working condition of } \\
\text { calculation }\end{array}$ & $\begin{array}{c}\text { anti-slide } \\
\text { safety } \\
\text { factor }\end{array}$ & \multicolumn{2}{|c|}{$\begin{array}{c}\text { foundation } \\
\text { stress } \\
{[\mathrm{kPa}]}\end{array}$} & $\begin{array}{c}\text { non-uniformity } \\
\text { coefficient }\end{array}$ \\
\cline { 3 - 6 } $\begin{array}{c}\text { fundamental } \\
\text { load } \\
\text { combination }\end{array}$ & $\begin{array}{c}\text { Working condition of } \\
\text { completion period }\end{array}$ & 1.712 & 169.19 & 135.78 & 1.246 \\
\cline { 2 - 6 } & $\begin{array}{c}\text { working condition of } \\
\text { retaining water in the } \\
\text { highest level }\end{array}$ & 1.542 & 155.11 & 113.79 & 1.363 \\
\hline \multirow{2}{*}{$\begin{array}{c}\text { special load } \\
\text { combination }\end{array}$} & $\begin{array}{c}\text { working condition of } \\
\text { retaining water in the } \\
\text { check water level }\end{array}$ & 1.666 & 108.27 & 71.39 & 1.517 \\
\cline { 2 - 6 } & $\begin{array}{c}\text { working condition of } \\
\text { sudden drawdown }\end{array}$ & 1.479 & 164.96 & 107.11 & 1.540 \\
\hline
\end{tabular}

\section{Wing Wall Stability Analysis}

Anti-slide safety factor of level 1 wing wall is not less than 1.35 when load combination is the fundamental combination, and it is not less than 1.2 when load combination is the special combination. Non-uniform coefficient of foundation is not greater than 2.0 when load combination is the fundamental combination and it is not greater than 2.5 when load combination is the special combination. The maximum of foundation stress is not greater than 1.2 times of foundation allowable load capacity. Those calculations demonstrate that anti-slide safety factor, the maximum of foundation stress and stress non-uniformity coefficient of wing walls are satisfied, so the design of wing wall is safety. 


\section{Epilogue}

The safety of sluice project or the water conservancy project is decided by stability of sluice chambers, the stability of the lock chamber is refers to that average basal stress of sluice chambers is not greater than allowable bearing capacity of foundation under different kinds of load combinations, obvious incline is not happen, the ratio of maximum and minimum foundation stress is not greater than admissible value, which may leads to slide along the ground or deep-layer; The function of wing wall on upstream area is not only to retain soil but to lead inflow to chambers smoothly. Besides, it helps blanket on anti-seepage; the function of wing wall on downstream area is not only to retain but to guide flow out of gate to diffuse uniformly along with wing walls, avoiding Backflow whirlpool's appearing. So, in order to determine the engineering stability and safety, the calculation and analysis of stability of sluice chamber and wing wall should be in accord with specification and combined with concrete engineering under different working conditions and load combination strictly.

\section{References}

[1]GB 50017-2002. Code for Design of Concrete Structures [S].

[2]SL265-2001. The Standard of Design Sluice [S].

[3] Wei Li. Hydraulic calculation handbook (second edition) [M]. Beijing: water conservancy and hydroelectric press, 2006. 